\title{
DUALITY OF LAND VALUE AND LAND USE: \\ An Analytical Study of the Guidelines Affecting Riverfront Revitalization in Cairo
}

\author{
Ahmed Mohamed Amin \\ Department of Architecture, Faculty of Engineering, Cairo University
}

Marwa Hassan Khalil

Rana Mostafa Hammam

Department of Architectural Engineering and Environmental Design, Faculty of

Engineering and Technology, Arab Academy for Science, Technology \& Maritime

Transport

\begin{abstract}
Land value can be defined as a product where supply and demand theory is applied. Land valuation depends upon the capability of development to be utilized in the best use and consequently the highest return. Waterfronts' parcels of land are of high land value being a strategic valuable urban resource for a city. This paper is concerned with studying the different factors influencing land value and land use, focusing on the physical factors, as well as extracting guidelines related to the factors previously analyzed. In addition, this paper investigates the perception of three categories: architects and urban planners, real estate experts, and lay people towards the relative weights of the extracted guidelines in their positive impact on land value and land use using a questionnaire. It is suggested that these guidelines would enhance compatibility between land value and land use, and accordingly it is expected to assist in the Nile riverfront revitalization process. Architects and urban planners, and lay people didn't rate the impact of any guideline with less than moderate impact. Moreover, results showed that the three categories agreed upon rating the guideline of public transportation and infrastructure to be of a very high impact on land value and land use. As well, they all agreed on rating the guideline of divided zones at river walk and sidewalk to be of a high impact on land value and land use.
\end{abstract}

Key words: Land value, Land use, Physical factors, Riverfront, Revitalization, Guidelines

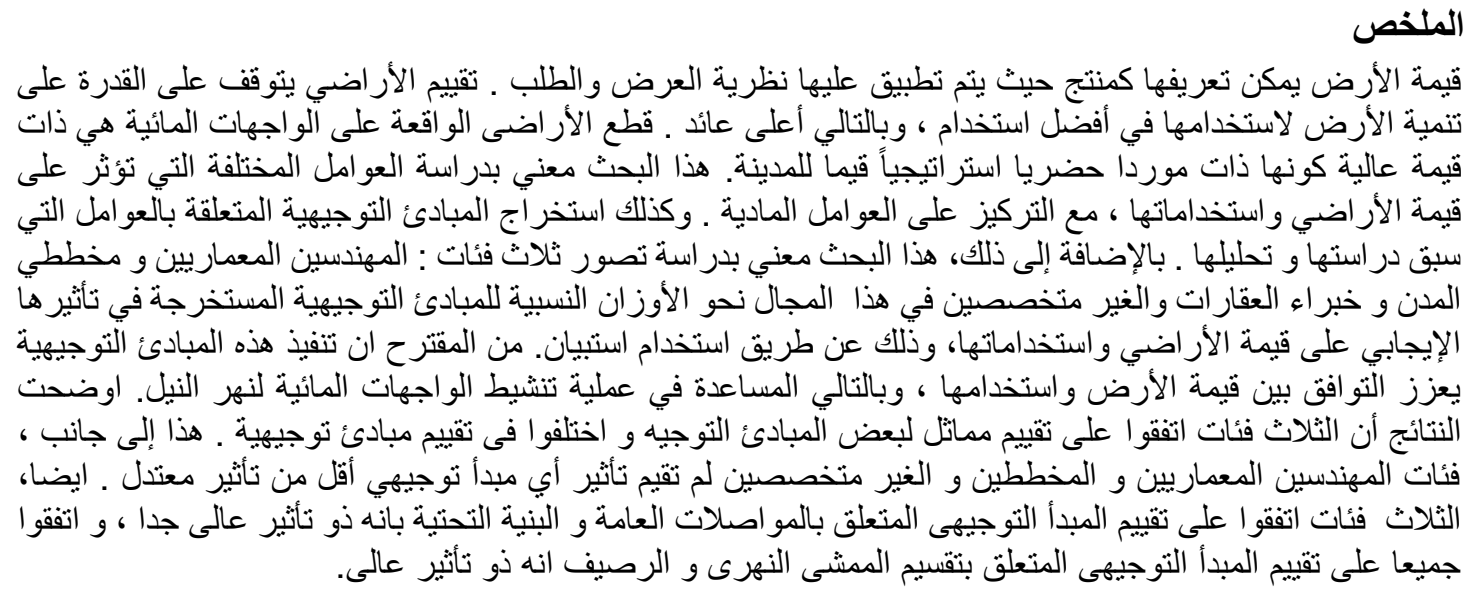




\section{INTRODUCTION}

Land value can be defined as a product where supply and demand theory is applied (Arizona Department of Revenue, 2001). Land valuation depends upon the capability to develop it to be utilized in the best use and consequently the highest return (Heikkila, 2000). One of the aspects that leads to high land value, is that a parcel of land having to be waterfronts premium or having accessibility to waterfront views (PA Consulting Group, 2009).

Waterfront is considered a 'strategic' valuable urban resource for a city. Its territorial position provides it with this major value for being precious, limited and nonrenewable asset. Actually, waterfront reflects the image of a city and emphasizes its urban identity. However, this identity has been weakened and altered over the years in many cities (Bruttomesso, 2006). This paper is concerned with Nile Riverfront in Cairo City. Actually, "Nile is a public resource for urban revitalization" in Cairo, (Kondolf, 2011, p.94). The Nile Riverfront has environmental, touristic, scenic, recreational and economic potentials. However, there are about $67 \%$ of riverfront parcels of land that are having land uses incompatible with their land value (URC, 2005). There are different factors, whether physical, social or political that influence both land value and land use (Arizona Department of Revenue, 2001). This goes back to the dual relationship between land value and land use, as according to Heikkila (2000) and Hubacek \& Bergh (2006), the urban land value is considered as a product in real estate economics, where its valuation depends on its utilization in the best land use. On the other hand, according to Olayiwola, et al. (2005) and Chakir and Parent (2009), to determine urban land use, land value is of major importance and should be considered.

This paper first studies the different factors influencing land value and land use, especially physical factors. Then, it focuses on studying the various guidelines extracted from the different factors previously analyzed. The paper suggests that implementing such guidelines at the Nile riverfront in Cairo is expected to have a positive impact on land value and land use, thus enhancing their compatibility, and accordingly assisting in the Nile riverfront revitalization process. Studying the factors influencing land value and land use, and the extracted guidelines is based on qualitatively analyzing data from previous studies and literature related to the field. After that, paper uses a questionnaire in quantitatively analyzing the perception of different categories towards the different relative weights of the extracted guidelines in their positive impact on land value and land use, and accordingly their impact on the revitalization process.

\section{FACTORS INFLUENCING LAND VALUE AND LAND USE}

Arizona department of Revenue (2001) and Topcu and Kubat (2009) pinpointed that accessibility, visual, environmental and security factors, and government regulations are the main factors influencing land value and land use. Beside, Arizona department of Revenue (2001) added the factors of location and physical characteristics of a parcel of land as well as supply and demand theory. In addition, Heikkila (2000) added the 
alternatives for land use. Moreover, Bourassa et al. (2004) and PA Consulting Group (2009) studied the view factor, being one of the important factors that influence land value. Topcu and Kubat (2009) classified the factors into four groups of factors, and some of these groups are broken down into tangible and intangible aspects. These groups are accessibility, environmental features, security and street density relationship. The Arizona department of Revenue (2001) classified the factors into four categories: economic; social, governmental and political, and physical factors. This paper focuses on the physical factors, as different literature discuss that their presence was one of the main reasons behind the success of riverfront revitalization projects causing a positive impact on land value and land use (Rodriguez et al, 2001), (PA Consulting Group, 2009), (PPS, 2010), (Chang and Huang, 2011), (Gunay and Dokmeci, 2011).

The physical factors are closely related to the urban context and are influencing the economic land value and land use. The physical factors are divided into two groups: factors related to the parcel of land, and factors related to context (Arizona Department of Revenue, 2001). The following section studies comprehensively the two groups of factors and the guidelines extracted from analyzing those factors that would have positive impact on land value and land use, hence enhancing their compatibility.

\subsection{Factors related to the parcel of land}

The factors discussed in this section are related to the parcel of land that influence its land value and land use. These factors are location of the parcel of land, its physical properties, the view from it, and alternatives of land uses for it.

\subsubsection{Location}

Land value varies according to the geographical location of the parcel of land. Some locations have their prestige which attract people more than other ones (Arizona Department of Revenue, 2001). The bid-rent theory that was developed by Alonso (1964) emphasizes that land rent tends to decrease with increasing distance from the central Business district. Land use changes as well with this change of land rent. Also, parcels of land overlooking a river; which are acting as waterfront are of high land value (PA Consulting Group, 2009). In addition, Cho (2009) studied that a parcel of land located nearby an open space, is of a high value, while Hartwick (2006) studied that a parcel of land located nearby an industrial area is of a low land value. Actually, the location of parcels of land overlooking a river is the main concern of this paper.

\subsubsection{Physical properties}

The physical properties of the parcel of land affects the costs of construction, operation and maintenance thus influence its land value. Concerning topography, flat land having the same level of the street is of high land value (Kok et al., 2011).

The presence of varying degrees in the slope of land where the parcel of land isn't in the same level of the street leads to a low land value (Kok et al., 2011). Concerning area of water-level parcels of land, the dimension of the frontage is more concerned 
than that of the depth (Colwell and Dehring, 2005). Hence, the extracted guideline from the factor of physical properties is that the ratio of frontage to depth of riverfront's parcel of land shouldn't exceed 1:3 (Charter of Township Waterford, 2013).

Not excceding the ratio of 1:3 results in a dual relationship between land value and land use. It would allow for maximum benefit of the frontage, hence raising land value of parcels of land at riverfront, and consequently attracting different compatible land uses. On the other hand, this ratio attracts different land uses leading to increase of demand on land which results in raising land value.

\subsubsection{View from parcel of land}

The views that have positive impact on land value and land use are the panoramic scenes of garden or water whether river, lake or ocean (Bourassa et al., 2004). Parcels of land on the waterfront are of limited supply and usually appeals to consumers for recreation or investment purposes. The factor of view differentiates between one parcel of land and the one next to it in terms of economic value. In Perth, Australia, the view of river added $28 \%$ to the value of land, and the view of garden, of a higher than average quality, adds $3 \%$ premium (Bourassa et al., 2004).

Bourassa et al (2004) and PA (2009) concluded that the view of river or park raises land value and agreed upon that the scope of view whether wide, medium or narrow, and the distance from river or park affects its view, and accordingly influences differently the value of a parcel of land. Moreover, providing facility for pedestrian's proximity to the river for totally viewing it influences land value and land use (Richmond City Council, 2012). Furthermore, Colwell and Dehring (2005) emphasized that parcels of land having lake fronts differ; lake-level parcels of land are of higher value than bluff parcels of land. Hence, there are different guidelines that could be extracted from the factor of view that can help in achieving an appropriate land value and a compatible land use at riverfront parcels of land such as:

\section{- Public Parks and green areas:}

Should be present at wide river banks with where there could be canopy trees, shrubs, ground cover, pedestrian \& bicycle lanes and pathways linking to them, and suitable hardscape for accommodating different uses as restaurants and pavilions (Fig. 1), (Port of Los Angeles, 2011). The presence of public parks or green areas results in a dual relationship between land value and land use. They provide the view of the green areas and river together resulting in raising land value of parcels of land at riverfront, and consequently attracting different compatible land uses. On the other hand, the view of green areas and river together attracts different land uses leading to increasing demand on land which results in raising land value.

\section{- Visual Corridors:}

They are pedestrian landscaped open areas providing an unobstructed view of the river from the streets leading to the river bank (Fig. 2), they should be present at 
regular intervals such as $400-600 \mathrm{~m}$ or corresponding to the existing street grid (URC, 2006) and (Department of New York City Planning, 2013).

The presence of landscaped visual corridors resulted in a dual relationship between land value and land use. As they allow unobstructed view of the river resulting in raising land value of parcels of land at riverfront and urban depth as well, and consequently attracting different compatible land uses. On the other hand, this unobstructed view of the river attracts different land uses leading to increaseing demand on land which results in raising land value.

Figure (1) Riverfront Park at Little Rock City in the U.S. State of Arkansas

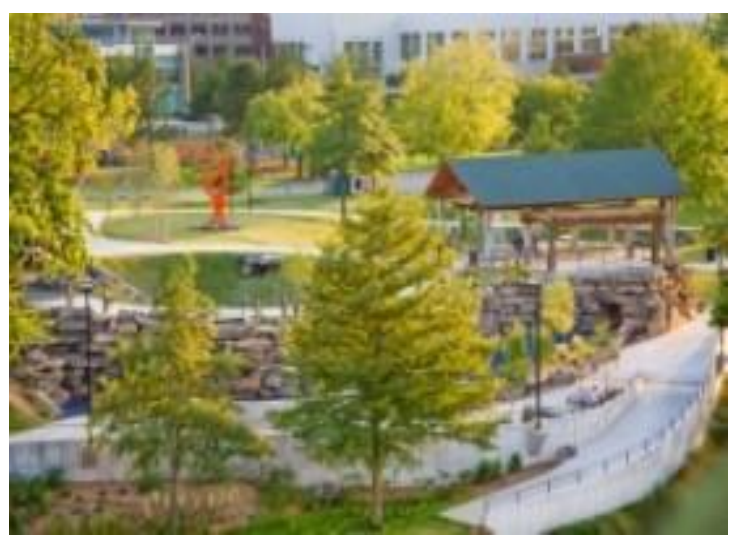

Source: (Little Rock, 2008)
Figure (2) Visual Corridor



Source: (Hamilton City Council, 2012)

\section{- Pedestrian's view of the river:}

Pedestrian's at riverfront parcels of land sidewalk and river walk should easily view the river. View of the river should be repeated every consistent distance between the public or private buildings at river bank (Fig.3), (Kruse, 2009).

\section{- Pedestrian's proximity to the river:}

Pedestrians should have the opportunity to get closer to the water's edge and view clearly the river. This could be through designing terraces and developing the river bank to be of a gradual slope with built in stairs (Fig.4), (Kruse, 2009).

Pedestrians' view of the river and proximity to the river enable better view of the river from both: sidewalk \& river walk leading to higher land value of parcels of land at riverfront, and consequently attracting different compatible land uses, such as restaurants and cafes, where guests can view the river while eating $\&$ drinking. On the other hand, allowing better view of the river attracts different land uses leading to increasing demand on land which results in raising land value. 
Figure (3) Consistent distance between buildings at river bank

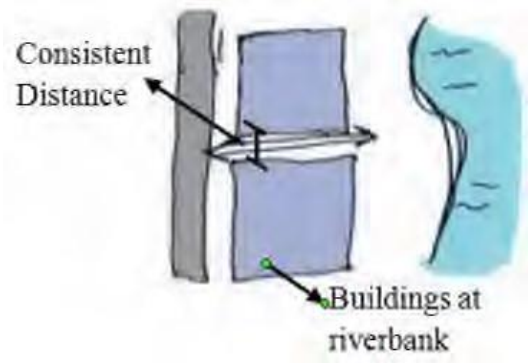

Source: (Kruse, 2009)
Figure (4) Terraces \& stairs at river bank.
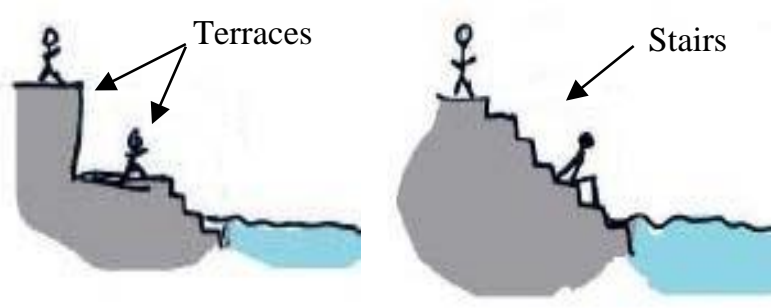

Source: (Kruse, 2009)

\subsubsection{Different Alternatives of land use for a parcel of land}

The presence of various alternatives for utilizing a parcel of land raises its value. These alternatives vary between residential, commercial, industrial and place of worship, where each use leads to a different economic return. Also, the presence of a mixed use system where a parcel of land can have different land uses leads to higher land value.

There are two different alternatives of land use allocations: zoning allocation and market allocation. Zoning allocation, which is also known as government allocation is the presence of parcels of land with defined land uses, while market allocation is the presence of parcels of land with undefined land uses. (Heikkila, 2000). In case of market allocation, the price of comparable parcels of land are equal across all uses, however in case of zoning allocation, price of comparable parcels of land differ according to the different uses (Heikkila, 2000). Also, Hubacek and Bergh (2006) studied that the land use of a parcel of land would affect the value of the surrounding parcels of land. Hence, the extracted guideline for government allocation of land use for riverfront parcels of land is to abide by the following preferred land uses: residential, touristic such as museums, hotels, restaurants, and cafes, flowers trade or green areas (General Administration of Urban Planning in Egypt, 1996). This will lead to a planned and zoned area resulting in higher land value of parcels of land at riverfront. On the other hand, this would attract the land uses decided by the method of government allocation of land use especially the nonresidential ones to benefit from the agglomeration factors so increases demand on land which results in raising land value. While, the extracted guidelines for market allocation of land use, is implementing the mixed use system for riverfront parcels of land (PPS, 2010). This attracts different land uses, as the investor is having the free of choice for the use or mixed uses to allocate in this land, hence increasing demand on land, leading to higher land value of parcels of land at riverfront.

\subsection{Factors related to context}

This section discusses the factors related to the area where the parcel of land is situated which influence the land value and land use of this parcel of land. These factors are accessibility, visual factors, and streetscape. 


\subsubsection{Accessibility}

Olayiwola et al. (2006) proved that there is a positive relationship between accessibility and improvement of transportation facilities. As transportation facility is available for a certain district which easies its accessibility; land value in this district starts to be higher. Also, Debrezion et al. (2011) emphasized that access via roads is not the only important aspect of accessibility, but also reliable public transportation and the availability of parking lots are important aspects. Hence, areas where transportation facilities is limited, when improving it, land value will consequently be raised. This was proved by Giuliano et al. (2010) that accessibility influences residential land value as households consider travel costs concerning the house they are willing to purchase. According to Du and Mulley (2007), in Tyne and Wear, which is a Metropolitan Region located in the North East of England, houses that are just 200500 meters away from metro station are having positive premium ranging from $5 \%$ to $50.09 \%$ of the houses price, and consequently land value is higher in this area. Moreover, Debrezion et al, (2011) and Waddell and Moore (2008) proved that accessibility influences the land value of offices, as land value of offices located nearby railway stations and airports increases, for easier accessibility of customers and labor force. Hence, accessibility influences land use as well, as it has an impact on the locations of houses and firms (Thakur, 2009 and Forkenbrock, 2001). Hence, there are different guidelines that could be extracted from the factor of accessibility that can help in achieving an appropriate land value and a compatible land use for riverfront parcels of land such as:

- Providing appropriate public transportation and infrastructure (Bloomberg, 2013):

a. Implementing Public buses' routes with bus stops at riverfront

b. Implementing Subway systems or tram line with stops at riverfront (Fig. 5).

c. Implementing vehicular bridges crossing the river

d. Providing river taxi (Fig. 5).

Figure (5) Public Transportation

Tram line along Nervion River in Bilbao City

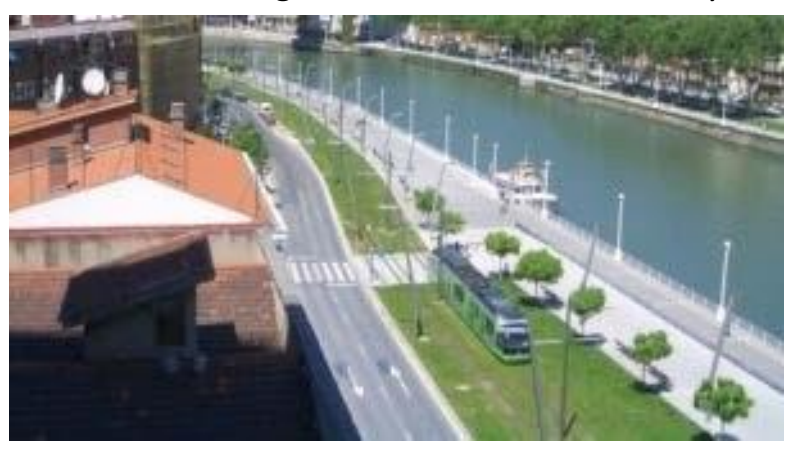

Source: (Skyscrapercity, 2005)
Water Taxi in Malacca River

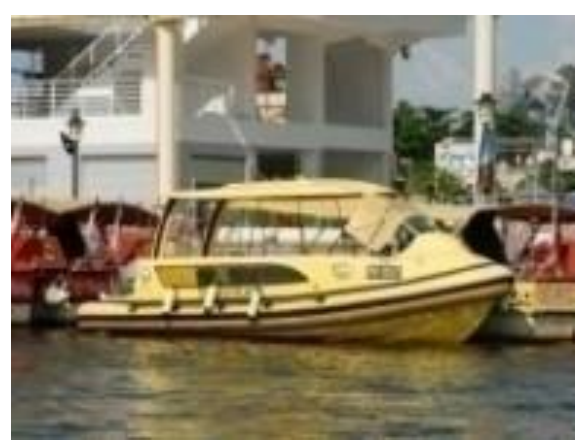

Source: (Skyscrapercity, 2011)

The presence of transportation infrastucture and different facilities lead to easier access of people to riverfront and river bank by road and river, resulting in raising land value of parcels of land at riverfront, and consequently attracting different compatible 
land uses. On the other hand, these publict transportation facilities attract different land uses which increases demand on land and results in raising land value.

\section{- Pedestrian Accessibility:}

a. Crosswalk: with a different texture and paving materials for pedestrians to cross the road and reach the riverbank (Luckett, 2007).

b. Pedestrian Bridges: connecting the city with the river bank (Fig.6), (Baraboo City Government, 2007).

Figure (6) London Millennium Bridge

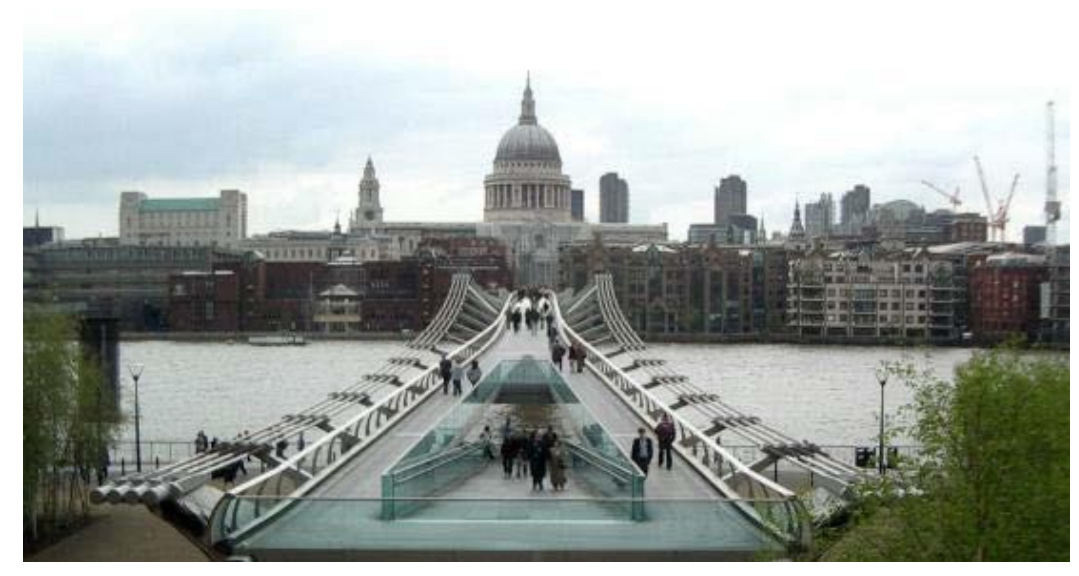

Source: (Tripadvisor, 2006)

The presence of different facilities of pedestrian accessibility leads to safe access of people to riverfront and river bank without the need of using a car, bus or ferry boat, resulting in raising land value of parcels of land at riverfront, and consequently attracting different compatible land uses. On the other hand, pedestrian accessibility attracts different land uses, and so increasing demand on land which results in raising land value.

\subsubsection{Visual Factors}

Visual factors are concerned with the architectural characteristics of the area where the plot of land is located. According to Topcu and Kubat (2009), there are visual factors which raise land value while others have little influence. Concerning buildings, harmony between buildings' facades and colors has the highest effect on land value, then the historical and architectural factors, and the least effect is that of the construction type and building structure. According to Gao and Asami (2007), visual factors including continuity of external walls, conformity of buildings' colors and materials, compatibility of buildings styles and beauty of skylines formed by buildings led to increase of land values in Tokyo and Kitakyushu by $1-1.5 \%$ and $3 \%$ respectively. Hence, there are different guidelines that could be extracted from the visual factors that can help in achieving an appropriate land value and a compatible land use for riverfront parcels of land such as: 


\section{- Building Heights:}

Buildings should be stepped back in height allowing view of the river and preventing the riverfront area from being dominated by the buildings (Fig.7), (Port of Los Angeles, 2011).

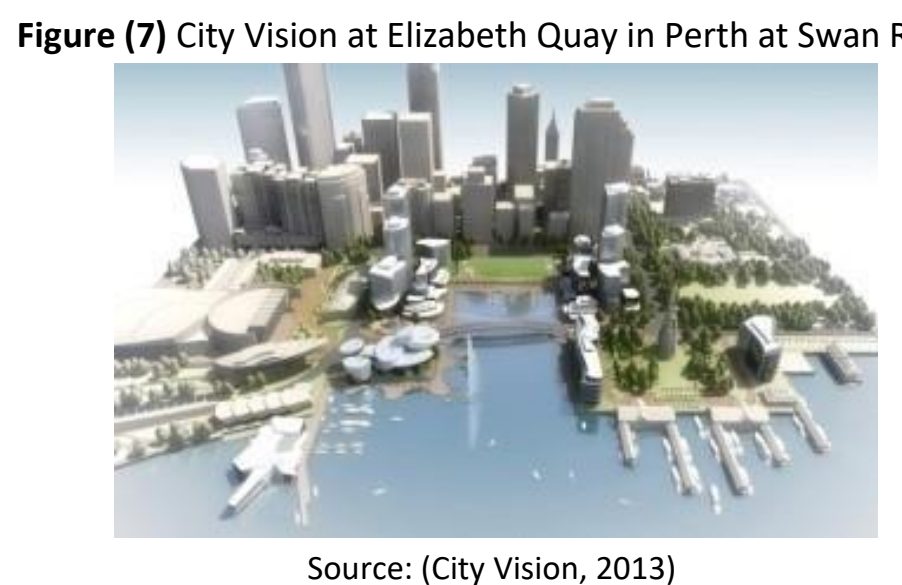

\section{- Building Setback:}

Front and side setbacks have to be consistent with other neighboring buildings. Front Setback is an outdoor room between the building and sidewalk can be used as residential building front zone where raised planters could be placed containing trees and shrubs adjacent to the building. Also, could be business front zone in case of a business use in the ground floor where it could be a window shopping zone or an outdoor seating area (Fig. 8), (Urban Code Handbook, 2004).

Figure (8) Building Front Setback

Residential building front zone

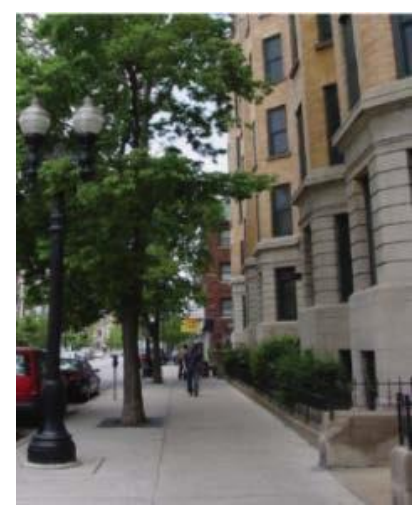

Source: (Chicago Department of Transportation and Transit, 2003)
Business front zone

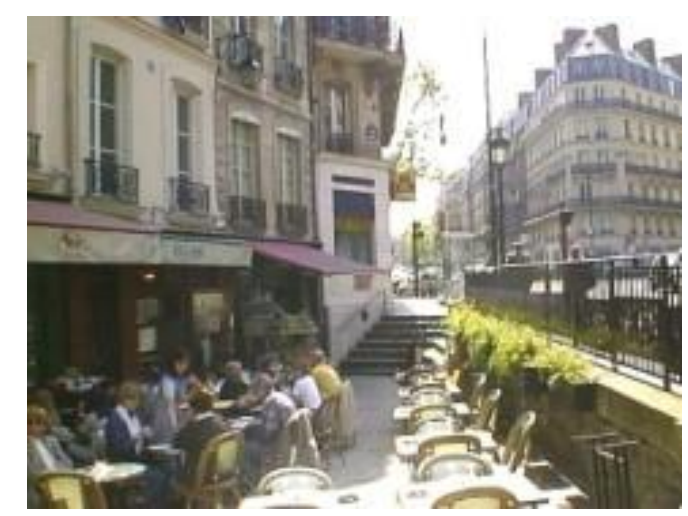

Source: (Playerbase, 1999) Bureau of Bridges

\section{- Building Façade:}

Should enhance pedestrians' visual interest through architectural details, articulation, visual continuity and environmental solutions, especially at ground and first floors in (Fig. 9), (Baraboo City Government, 2007 \& (City of Los Angeles Department of City Planning, 2008). 
Figure (9) Building Façade with and without (a) Architectural Details, (b) Articulations, (c) Visual Continuity and (d) Environmental Solutions

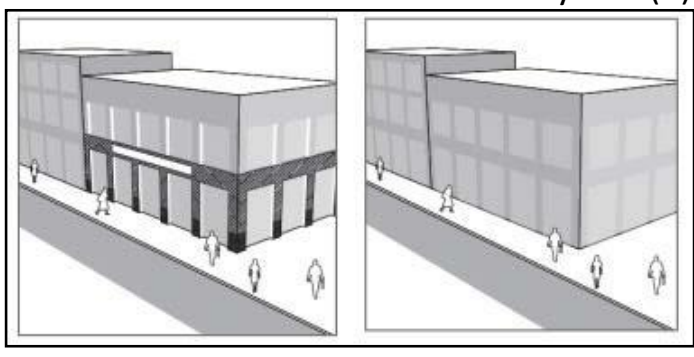

(a)

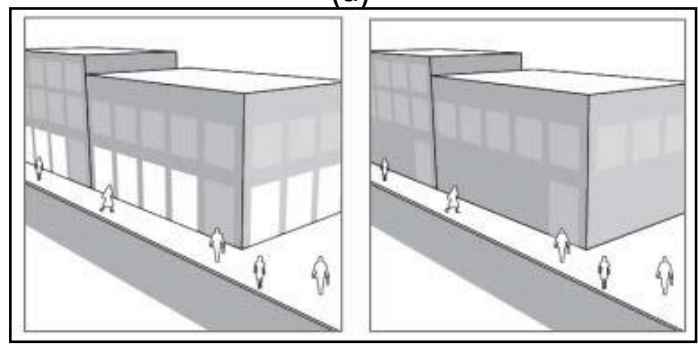

(c)

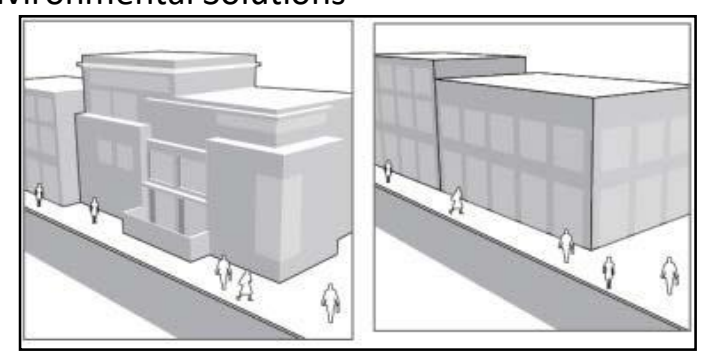

(b)

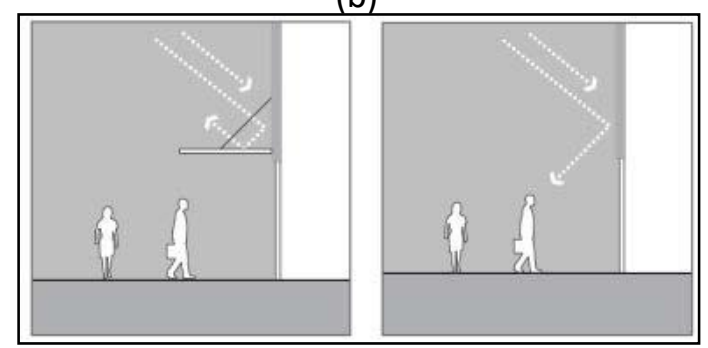

(d)

Source: (City of Los Angeles Department of City planning, 2008)

\section{- Building Signage:}

Sign banners attached at building façade has to be either flush with the façade of the building, or at the façade's awning or projected perpendicular on the façade, (Fig. 10). They should enhance the heritage of the building, don't hide it's architectural details and be scaled with respect to pedestrians (Baraboo City Government, 2007).

Figure (10) Building Signage

Projected Signage

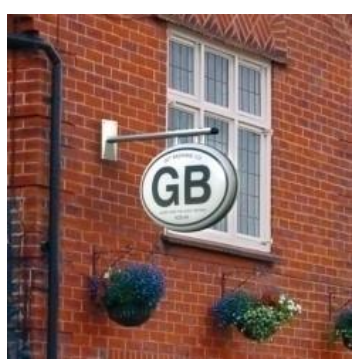

Source: (Total Branding Solutions, 2012)
Awning Signage

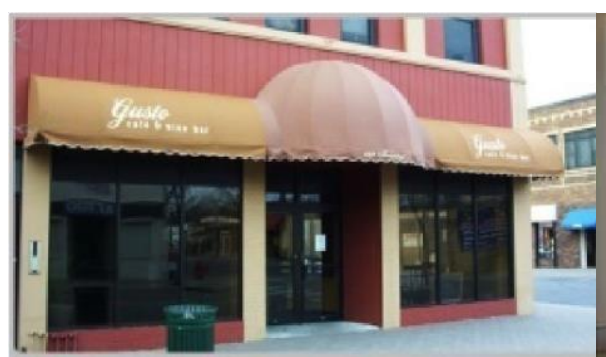

Source: (Sign Source, 2011) Signage flush at building façade

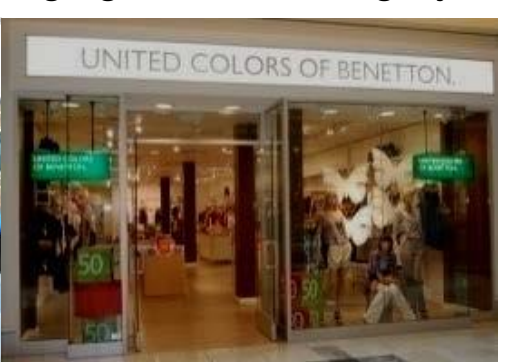

Source: (The Shop at Willow Bend, 2012)

The presence of stepped height of buildings, building setback and interesting building façade at riverfront building enhances the visual character of the built environment surrounding the riverfront area, leading to higher land value of parcels of land at riverfront, and consequently attracting different compatible land uses. On the other hand, this enhanced visual character would attract different land uses lading to increase of demand on land which results in raising land value. 


\subsubsection{Streetscape}

Eves (2009) proved that good streetscape has a positive significant impact on value of residential properties and so on land value and land use. Elements of good streetscape include hardscape elements as covering materials of sidewalks, lighting, planters \& furnishing elements, and softscape elements as trees and plantings (Luckett, 2007). According to Gao \& Asami (2007), streetscape elements including greenery of open pedestrian spaces, decorations and street furniture raised land value. Hence, there are different guidelines that could be extracted from the factor of streetscape that can help in achieving an appropriate land value and a compatible land use for riverfront parcels of land such as:

\section{- River walk/ Sidewalk:}

There should be a river walk which is a sidewalk separating the road overlooking the river from the river bank (Fig. 11), (Westchester County Planning Department, 2005), as well as a sidewalk separating riverfront building from the road overlooking the river (Fig. 12), (Downtown Alliance Streetscape Committee, 2006). River walk/ Sidewalk should be divided into amenities zone and walking zone, in addition to building zone at sidewalk. Their most recommended paving materials aesthetically and functionally are concrete and brick (Capital City Development Corporation, 2009).

The well maintained riverwalk and sidewalk will enhance them visually and functionally leading to higher land value of parcels of land at riverfront, and consequently attracting different compatible land uses. On the other hand, the well maintained river walk and sidewalk atrracts different land uses, so increases demand on land which results in raising land value.

Figure (11) River Walk

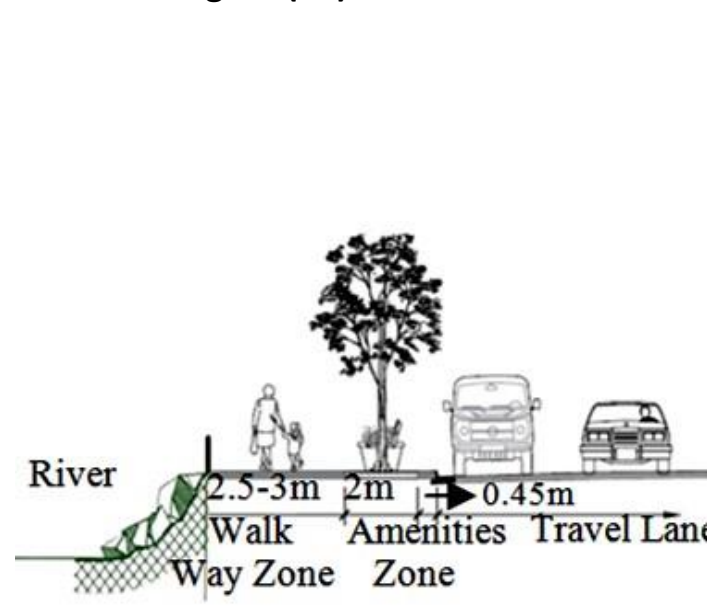

Source: (Westchester County Planning

Department, 2005)
Figure (12) Sidewalk

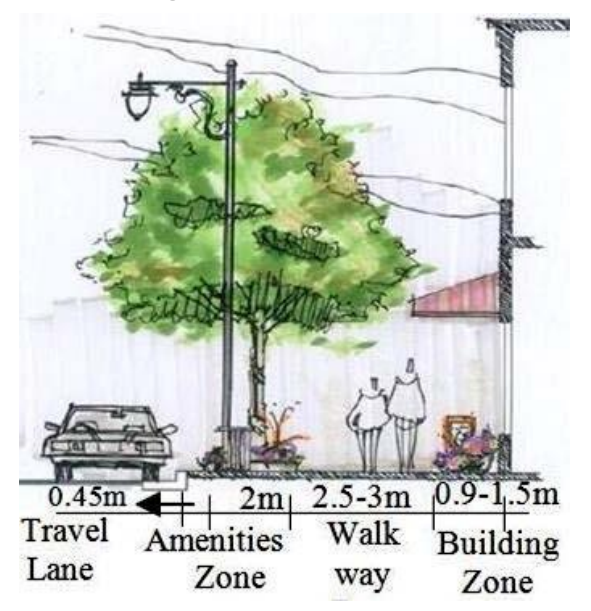

Source: (Downtown Alliance Streetscape Committee, 2006)

\section{- Trees:}

There should be a line of trees at the river walk/ sidewalk for reducing air pollution and acting as a shade for pedestrian, and are recommended to be deciduous trees 
(Luckett, 2007). They could be fixed either as single tree in tree grate or single tree in raised planter or grouped tress in planter or trees in a grassed parkway, (Fig. 13), (Downtown Alliance Streetscape Committee, 2006).

Figure (13) Types of tree fixation:

(a) Single tree in grate, (b) Single tree in raised planter,

(c) Grouped trees in concrete curbed planter and (d) Grouped trees in grassed parkway

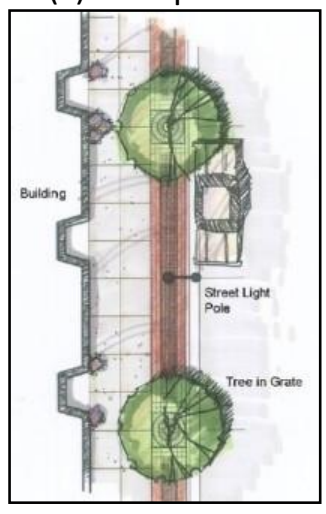

(a)

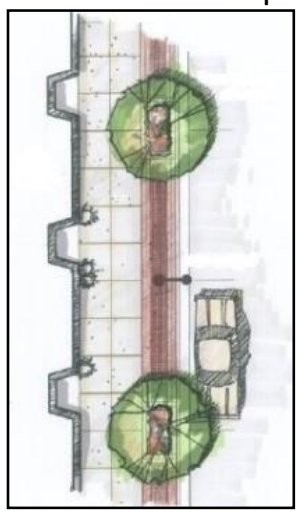

(b)

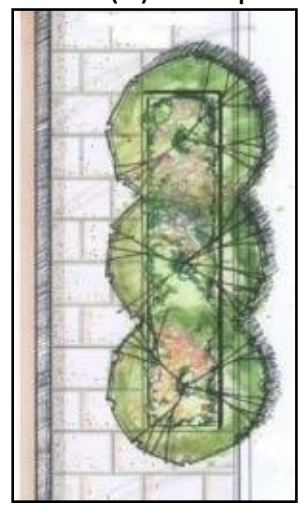

(c)

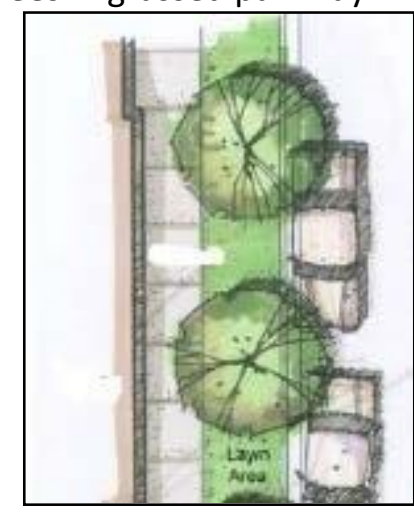

(d)

Source: (Downtown Alliance Streetscape Committee, 2006)

\section{- $\quad$ Lighting:}

There should be post mounted lights at the river walk/ sidewalk for vehicles and pedestrians (Fig.14), (Luckett, 2007).

Figure (14) Lighting Posts for Vehicles and Pedestrians.
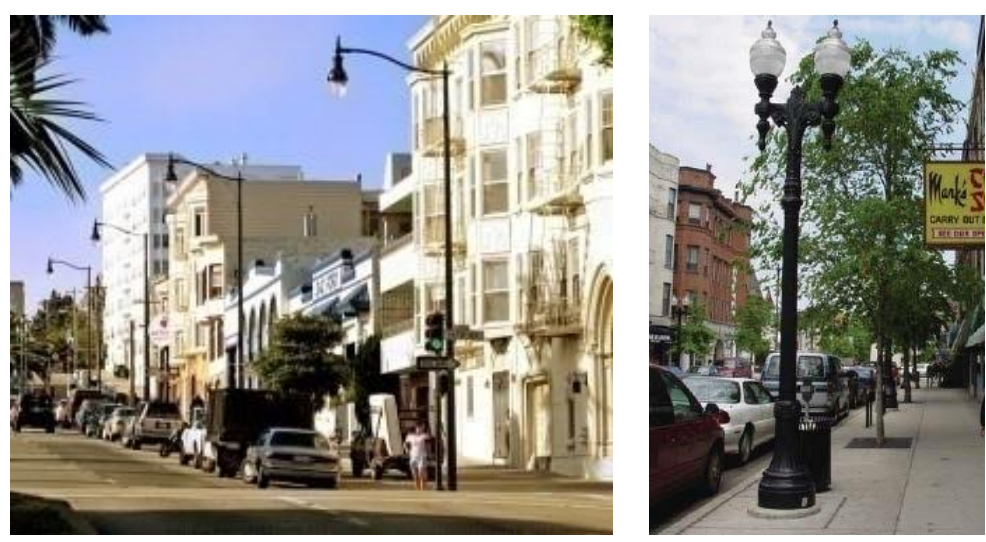

Source: (SFMTA, 2013) and (Chicago Department of Transportation Bureau of Bridges and Transit, 2003)

\section{- Signage and advertisement banners at river walk/sidewalk:}

Banners can be fixed at lamp posts at amenities zone, where banners are positioned perpendicular to the river walk/sidewalk or fixed at posts built in the fence at river walk or advertisement banners could be fixed in "sandwich board signage" which should be structurally stable under all weather conditions, (Fig. 15), (Piwoni, 2006) and (Wilmington Area Metropolitan Planning Organization, 2008). 
Figure (15) Streetscape Signage
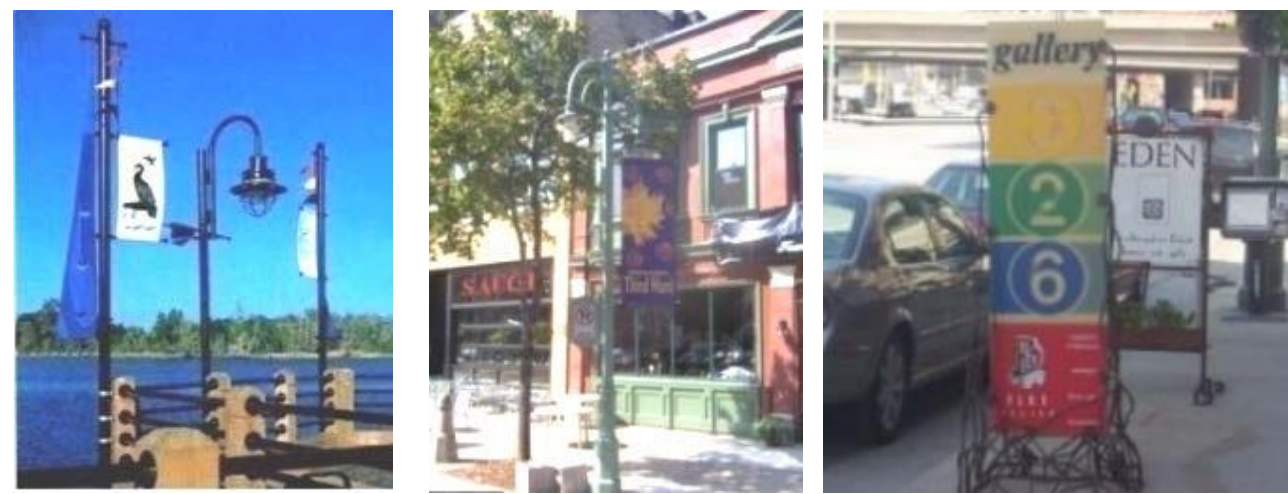

Source: (Wilmington Area Metropolitan Planning Organization, 2008) and (Piowni, 2006)

\section{- Furniture:}

It includes benches, litter receptacles and bicycle racks, bollards and fences as seen in Fig. (16) \& fig. (17), (Luckett, 2007). Seating elements and benches could be placed parallel to the river walk/sidewalk, or perpendicular to the street facing another one for encouraging group conversation or placed back to back for privacy, as seen in Fig. (16), (PPS, 2009).

Figure (16) Benches

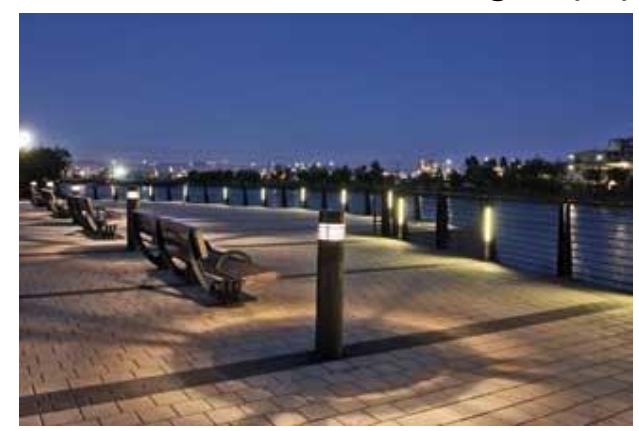

Source: (HLB,2006)

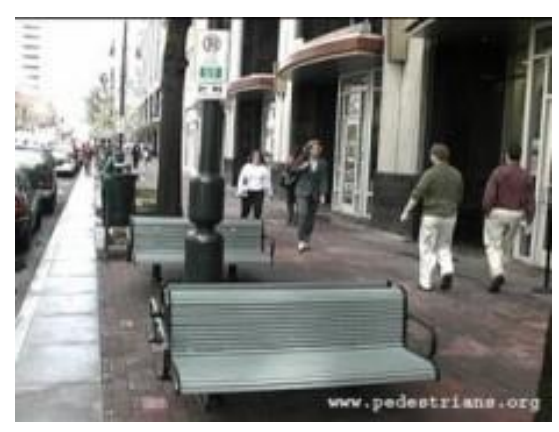

Source: (Pedestrians, 2012)

Litter receptacle should be having a side opening, and should be placed near the seating and away from direct sunlight rays, (Fig. 17) (Luckett, 2007) and (Capital City Development Corporation, 2009). Bollards are arranged in a line acting as a barrier at river walk/sidewalk against motor vehicles. They should be spaced allowing wheel chairs and preventing vehicles, shouldn't be shorter than standard to be prevent tripping hazards, and can be having built in light for pedestrians, (Fig. 17) ,(TransAlt, 2007). Fences: are located between river edge and river walk, should be designed with minimum obstruction of the view of the river, preferred that its handrail be made of wood to be more comfortable and to have built in lighting bollards, (Fig.17), (FEMA, 2007).

The presence of lighting, signage and furniture elements at the river walk and side walk enhances the sence of comfortability, security, vitality and interaction between people leading to higher land value of parcels of land at riverfront, and consequently attracting different compatible land uses. On the other hand, those enhanced senses atrracts different land uses, so increases demand on land which results in raising land value. 
Figure (17) Furniture Elements

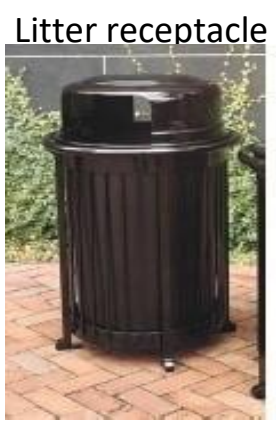

Source: (Downtown Alliance Streetscape Steering Committee, 2006)
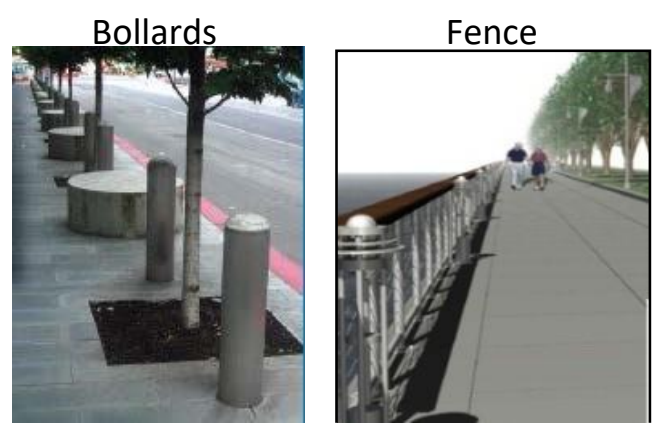

Source: (FEMA, 2007)

(City of Oshkosh Community Development Department, 2006)

Hence, it is clear that the riverfront revitalization guidelines extracted from the different physical factors, summarized in Table (1), impact land value and land use and result in a dual relationship between them in different ways. However, there are different levels of the impact of these guidelines, which is the main concern of the following section.

Table (1) Different Guidelines extracted from each factor

\begin{tabular}{|c|c|}
\hline Factors & Guidelines \\
\hline Physical Properties & $\begin{array}{l}\text { Riverfront parcel of land's frontage to depth ratio not to be exceeding } \\
1: 3\end{array}$ \\
\hline \multirow[t]{4}{*}{ View } & Public parks or green areas \\
\hline & Visual corridors \\
\hline & Pedestrian's view of the river \\
\hline & Pedestrian's proximity to the river \\
\hline \multicolumn{2}{|c|}{$\begin{array}{l}\text { Different Alternatives Residential, touristic as museums or hotels or restaurants and cafes, of Land } \\
\text { Use flowers trade or green areas, through government land use allocation Mixed Use System } \\
\text { through market land use allocation }\end{array}$} \\
\hline \multirow[t]{2}{*}{ Accessibility } & $\begin{array}{l}\text { Public transportation and infrastructure through implementing public } \\
\text { buses' routes, subway metro systems or tramline with stops at riverfront }\end{array}$ \\
\hline & Pedestrian Accessibility through cross walks and pedestrian bridges \\
\hline \multirow[t]{4}{*}{ Visual factors } & Low river front's building height \\
\hline & Building front setback \\
\hline & $\begin{array}{l}\text { Building façade having architectural details, articulations, visual continuity } \\
\text { and a environmental solutions }\end{array}$ \\
\hline & $\begin{array}{l}\text { Building signage enhance the heritage of the building, not hiding it's } \\
\text { architectural details, and scaled with respect to pedestrians }\end{array}$ \\
\hline \multirow[t]{6}{*}{ Streetscape } & Wide river walk and sidewalk \\
\hline & Divides zones at river walk and sidewalk \\
\hline & Tress at river walk and sidewalk \\
\hline & Vehicular \& Pedestrian lighting post \\
\hline & $\underline{\text { Signage at river walk and sidewalk }}$ \\
\hline & $\begin{array}{l}\text { Furniture elements: benches, litter receptacles, bicucle racks, bollards and } \\
\text { fence }\end{array}$ \\
\hline
\end{tabular}




\section{RELATIVE IMPACT OF GUIDELINES AS PERCEIVED BY DIFFERENT CATEGORIES}

The extracted riverfront revitalization guidelines are suggested to have positive impact on land value and land use on different levels. To investigate this, the perception of three different categories towards the relative weights of the impact of the extracted guidelines is conducted using a questionnaire. The following section is discussing the questionnaire's objective, methodology and results.

\subsection{Objective of the Questionnaire}

The objective of this questionnaire is to investigate the perception of three categories: architects and urban planners; real estate experts; and lay people towards the relative weights of the extracted guidelines through determining the extent of positive impact each guideline has on land value and land use of parcels of land at river front. The results of this questionnaire are expected to aid in the Nile Riverfront revitalization process.

\subsection{Methodology of the Questionnaire}

The questionnaire is handled using five-point Likert scale (Sekaran \&Bougie, 2009), where 1= very low impact, $2=$ low impact, $3=$ moderate impact, $4=$ high impact and $5=$ very high impact. The 20 guidelines mentioned on Table (1) was asked about in the questionnaire as seen in the example on Fig. (18). The respondents were 30 from each category, all living and working in Cairo, where $70 \%$ of the category of architects and urban planners were having more than ten years of experience, while all real estate experts were having more than ten years of experience. The sample chosen for the lay people category was chosen to be homogeneous between the different categories of the society, with diversity in gender, socio-economic level, and occupation. The results are analyzed statistically using the mode to obtain the average, which reveals the rating with the highest number of respondents, as according to Chandan (2009), the mode is the most suitable measure for qualitative data.

Figure (18) Questionnaire Format

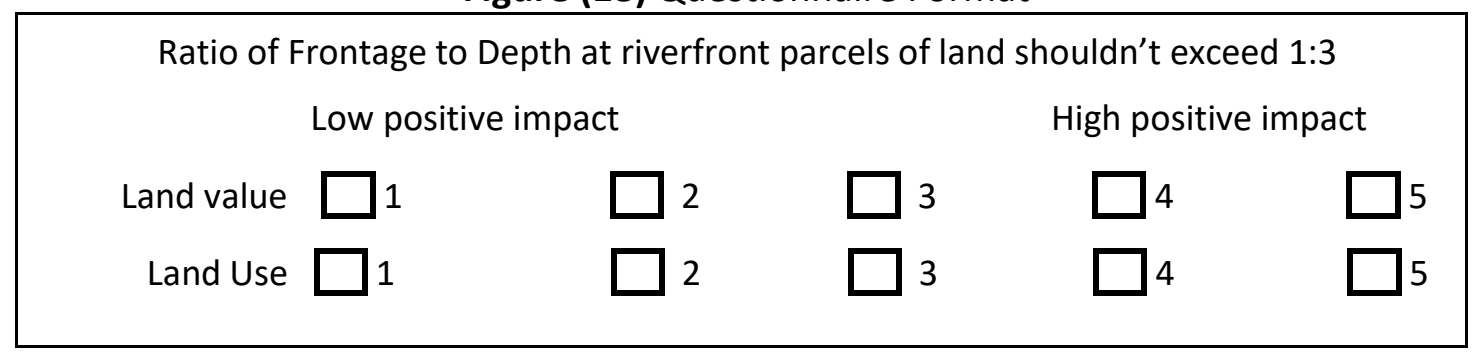

\subsection{Results of the Questionnaire}

Most of the respondents rated the impact of the same guideline on land value and land use equally in the different questions, except for $5 \%$ to $15 \%$ of the respondents in the three categories rated land value and land use differently (Fig.19). Hence, emphasizing the duality of land value and land use, as they are inter-reliant, where land value influences land use and vice versa. The three categories of architects \& 
urban planners, real estate experts and lay people, have different perceptions for the relative weights of the guidelines in affecting land value and land use. However, their perceptions are not extremely different, as they all agree on the same rating for some guidelines, and other guidelines that are not having equal rating from all of the categories; the difference between them is one degree rating in most of the cases. Architects and urban planners agreed on the following order of guidelines from these of higher impact to those of lower impact on both land value and land use:

\section{Very high impact}

- Public parks and green areas at river bank

- Public transportation \& infrastructure

\section{High impact}

- Riverfront parcel of land's frontage to depth ratio not to be exceeding 1:3

- Visual corridors

- Pedestrian's view of the river

- Pedestrian's proximity to the river

- Wide river walk and sidewalk

- Divided zones at river walk and sidewalk

- Trees at river walk and sidewalk

- Vehicular lighting posts at river walk and sidewalk

- Pedestrian lighting posts at river walk and sidewalk

- Streetscape Furniture as benches, litter receptacles, bicycle racks and bollards

\section{Moderate impact}

- Government land use allocation

- Market land use allocation

- Pedestrian bridges

- Crosswalks

- Low river front's building height,

- Building front setback

- Building façade having architectural details, articulations, visual continuity and a environmental solutions

- Presence of signage at river walk \& sidewalk.

- Presence of trees at river walk and sidewalk

Hence, according to the category of Architects and urban planners, there weren't any of the extracted guidelines that were rated as having low or very low impact.

While real estate experts agreed on the following order of guidelines from these of higher impact to those of lower impact on both land value and land use:

\section{Very high impact}

- Presence of public parks and green areas at river bank 
Land value

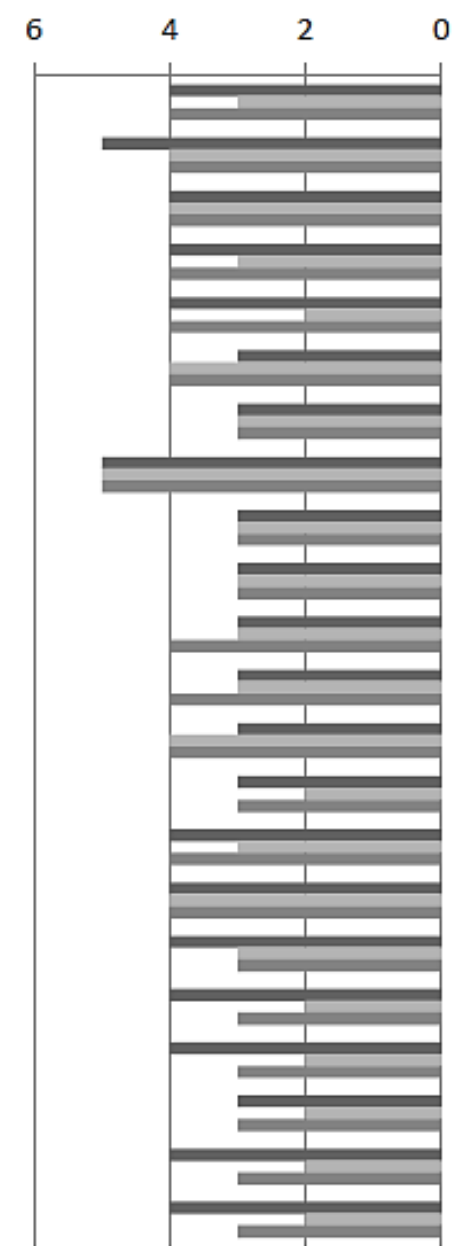

Frontage to Depth ratio

Public parks at river bank

Visual Pedestrian Corridors

Pedestrians' view of the river

Physical Access

Government Land Use Allocation

Market Land Use Allocation

Public Transportation \&Infrastructure

Crosswalk

Pedestrian Bridges

Building Height

Building setback

Building Façade

Building Signage

River walk/ Sidewalk Width

River walk/ Sidewalk divided zones

Trees at River walk/ Sidewalk

Vehicular lighting Post

Pedestrian lighting Post

Signage at River walk/ Sidewalk

Benches \& Litter receptacles

Bicycle Rack \& Bollards
Land Use

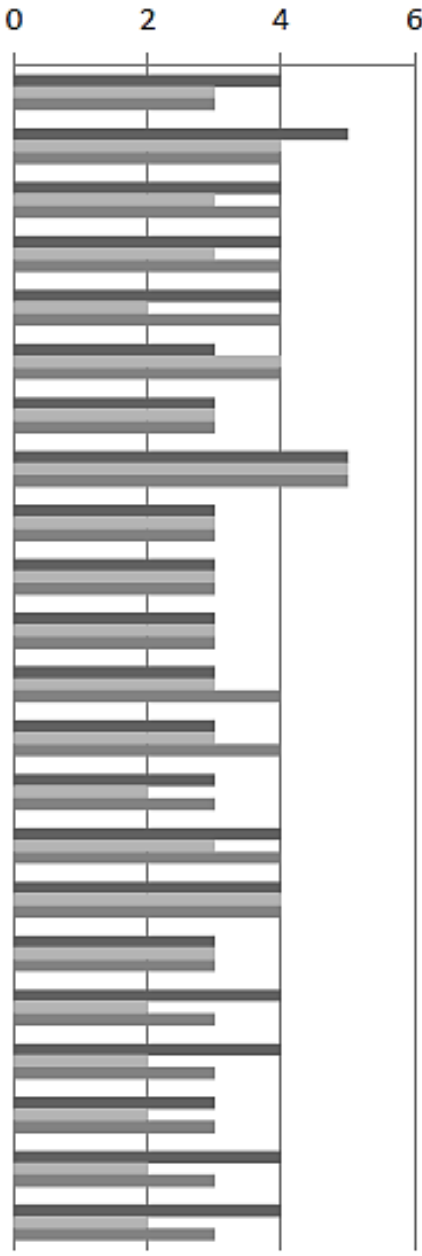

Architects \& Urban Planners

Real Estate Experts

Lay People

\section{High impact}

- Presence of public parks and green areas at river bank

- Visual corridors

- Government land use allocation

- Building façade to be having architectural details, articulations, visual continuity and environmental solutions

- Divided zones at river walk and sidewalk

But visual corridors and building façade were rated to be of moderate impact on land use

\section{Moderate impact}

- $\quad$ Riverfront parcel of land's frontage to depth ratio not to be exceeding 1:3

- Provision of pedestrian's view of the river

- Market land use allocation,

- Pedestrian bridges

- Crosswalks 
- Low river front's building height

- Building front setback

- Wide river walk \& sidewalk,

- Trees at river walk and sidewalk

\section{Low impact}

- Pedestrian's proximity to the river,

- Building signage

- Vehicular lighting posts at river walk and sidewalk

- Pedestrian lighting posts at river walk and sidewalk,

- Signage at river walk and sidewalk

- Streetscape furniture as benches, litter receptacles, bicycle racks and bollards

Hence, according to the category of real estate experts, the guideline concerning public transportation \& infrastructure was the only one rated to be of very high impact. Besides, most of the guidelines that were rated to be of low impact were related to streetscape.

As well, lay people agreed upon the following order of guidelines from these of higher impact to those of lower impact on both land value and land use:

\section{Very high impact}

- Presence of public parks and green areas at river bank

\section{High impact}

- Riverfront parcel of land's frontage to depth ratio not to be exceeding 1:3

- Public parks and green areas at river bank

- Visual corridors

- Pedestrian's view of the river

- Pedestrian's proximity to the river

- Government land use allocation,

- Low river front's building height

- Building front setback,

- Wide river walk and sidewalk

- Divided zones at walk and sidewalk

\section{Moderate impact}

- Market land use allocation

- Pedestrian bridges

- Crosswalks,

- Building façade to be having architectural details, articulations, visual continuity and environmental solutions

- Building signage,

- Vehicular lighting posts at river walk and sidewalk

- Pedestrian lighting posts at river walk \& sidewalk,

- Trees at river walk and sidewalk,

- Signage at river walk and sidewalk,

- Streetscape furniture as benches, litter receptacles, bicycle racks and bollards 
Hence, the category of lay people is common with the category of architects \& urban planners in that there weren't any guideline that was rated as of low or very low impact. Besides, the category of lay people is common with the category of real estate experts in that the only guideline that was rated to be of very high impact was that related to public transportation and infrastructure.

It is clear from the results of this questionnaire that the three categories agreed on public transportation and infrastructure to be of very high impact. As well they all agreed on rating the guideline of divided zones at river walk \& side walk to be of high impact. In addition, they all agreed on rating market allocation of land uses through being of mixed use system, presence of pedestrian bridges and cross walks to be of moderate impact.

\section{CONCLUSION}

For a successful revitalization process of Nile River Fronts, this paper studied the different factors influencing land value and land use. The factors are divided into four categories: economic, social, governmental and political, and physical factors; focusing specifically on the physical factors. The physical factors are divided into two groups: factors related to parcel of land and factors related to context. Guidelines, related to each factor were extracted, as shown on Table (1), that if were applied, are expected to help in achieving an appropriate land value and hence, a compatible land use for riverfront parcels of land. This paper studied the extracted guidelines and investigated the relative weights of these guidelines in their positive impact on land value and land use, through quantitatively analyzing the perception of three categories: architects and urban planners, real estate experts, and lay people using a questionnaire. The questionnaire results emphasized the duality between land value and land use as the three categories almost rated equally the impact on land value and land use of the same guideline. In addition, the results showed that three categories rated the guideline of public transportation and infrastructure to be of a very high impact on land value and land use. Also they all rated the guideline of divided zones at river walk and sidewalk to be of a high impact. Besides, they all agreed on the rating of a moderate impact for the guidelines of market allocation (allowing mixed use system), presence of pedestrian bridges, and cross walks. Hence, the factors of accessibility, different alternatives of land use and streetscape are the most factors having positive impact on land value and land use. Therefore, the results of this questionnaire are expected to aid in the Nile Riverfront revitalization process as it shows clearly the important guidelines that need to be taken into consideration in order to guide a successful revitalization process enhancing the compatibility between land value and land use.

In fact, more research and studies related to the revitalization of Nile River fronts in Cairo, in general, are needed taking into consideration all other aspects of the revitalization process. This may include the implementation techniques, strategies, priorities, feasibility and frameworks organizing the relation between the different parties involved in the revitalization process. 


\section{References:}

Arizona Department of Revenue. (2001). Land Manual, Phoenix. Property Tax Division

Alonso, W. (1964). Location and land use: Towards a general theory of land rent. Cambridge, MA, USA: Harvard University Press

Baraboo City Government. (2007) Ringling Riverfront Design Guidelines. [Online] Available from: http://www.cityofbaraboo.com/vertical/sites/\%7BD06131C5-F452-44C7954E97BD998BCA20\%7D/uploads/\%7BE67F168B-3F12-41D0-98D95F417496D0A8\%7D.PDF [Accessed $1^{\text {st }}$ May 2013]

NYCEDC. (2013) A Stronger, More Resilient New York. [Online] Available from: http://www.nycedc.com/sites/default/files/filemanager/Resources/Studies/Stronger_ More_Resilient_NY/Ch14_Brooklyn_Queens_FINAL_singles.pdf

Bourassa, SC.et al. (2004) What's in a view? Environment and planning A. 36(8). p. 1427- 1450.

Bruttomesso, R. (2006) Waterfront redevelopment: A strategic choice for cities on water. International Waterfront Speakers Luncheon IV. $3^{\text {rd }}$ March 2006, Venice: Harbor Business Forum

Capital City Development Corporation. (2009). Downtown Boise Streetscape Standards \& Specifications Manual. [Online] Available from: http:// www.ccdcboise.com [Accessed $1^{\text {st July 2013] }}$

Chakir, R. \& Parent, O. (2009) Determinants of land use changes: A spatial multinomial profit approach. Papers in Regional Science. 88(2). p. 327-344.

Chandan J. (2009) Statistics for Business and Economics. Noida: Vikas Publishing House, Pvt Ltd.

Chang, T. \& Huang, S. (2011) Reclaiming the City: Waterfront Development in Singapore. Urban Studies. 48 (10). p. 2085-2100.

Charter of Township of Waterford. (2013) Code of Ordinances. Michigan: Order of Township Board.

City Vision. (2013) Elizabeth Quay: City Vision Alternative Concept Feb 2013. [Online] Available from: http://www.cityvision.org.au/wpcontent/uploads/2013/03/cityvisionwaterfront-1.jpg [Accessed 30 ${ }^{\text {th }}$ November 2013]

Cho, S. et al. (2009) Spatial and Temporal Variations in the Housing Market of Lot Size and Open Space. Land Economics. 85(1). p. 51-73.

Chicago Department of Transportation Bureau of Bridges and Transit. (2003). Streetscape Guidelines. [Online] Available from:

http://www.cityofchicago.org/dam/city/depts/cdot/Streetscape_Design_Guidelines.p df [Accessed $5^{\text {th }}$ November 2012]

City of Los Angeles department of city planning. (2008). Walkability Checklist Guidance for Entitlement Review. [Online] Available from:

http://www.urbandesignla.com/walkability/LA_Walkability_Checklist.pdf [Accessed $20^{\text {th }}$ July 2013].

City of Oshkosh Department of Community Development. (2006) Fox River Corridor Riverwalk Plan and Design Guidelines. [Online] Available from: 
http://www.ci.oshkosh.wi.us/Community_Development/Planning_Services/ [Accessed $15^{\text {th }}$ July 2013].

Colwell, P. \& Dehring, C. (2005). The Pricing of Lake Lots. The Journal of Real Estate Finance and Economics. 30 (3). p. 267-283.

Debrezion, G. et al. (2011). Chapter 3: The Impact of Accessibility on the Value of Offices. In Nunen, J. et al. (eds.). Transitions towards Sustainable Mobility. Heidelberg: Springer. p. 41- 57.

Department of New York City Planning. (2013) Zoning Tools: Waterfront Zoning. [Online] Available from:http://www.nyc.gov/html/dcp/html/zone/zh_ztools_waterfront.shtml [Accessed $1^{\text {st }}$ December 2013].

Downtown Alliance Streetscape Steering Committee (2006). Downtown Streetscape Design Guidelines. Grand Rapid: Downtown Alliance.

Du, H. \& Mulley, C. (2007) Transport accessibility and land value: a case study of Tyne and Wear. RICS Research paper series, 7(3). p.1-48.

Federal Emergency Management Agency (FEMA). (2007) Risk Management Series: Site and Urban Design for Security, Guidance Against Potential Terrorist Attacks. Oakland: Earthquake Engineering Research Institute.

Forkenbrock, D. et al. (2001). Transportation Investment and Urban Land Use Patterns. Public Policy Center: Transportation Policy Research, University of lowa

Eves, C. (2009) Assessing the impact of streetscape on residential property in lower to middle socio-economic areas. In: 16th Annual European Real Estate Society Conference, Stockholm: Royal Institute of Technology.

Gao \& Asami (2007). Effect of urban landscapes on land prices in two Japanese cities. Landscape and Urban Planning, Vol. 81. p. 155-166.

General Administration of Urban Planning. (1996). Nile Cornishe development project in Greater Cairo. Cairo's Governorate, Planning Research Department. (Arabic Reference)

Giuliano, G. \& Agrawal A. (2010) Public Transit as a Metropolitan Growth Strategy, in Pindus et al (Eds), Urban and Regional Policy and Its Effects, Vol.3, Washington, DC: Brookings Institution Press. p. 205-252.

Gunay, Z., \& Dokmeci, V. (2011) Culture-led regeneration of Istanbul waterfront: Golden Horn Cultural Valley Project. Cities. 29(4). p. 213-222.

Hamilton City Council (2012). Proposed district plan. [Online] Available from: http://www.hamilton.co.nz/ourcouncil/councilpublications/districtplans/proposeddi strictplan/appendix1/Pages/Appendix-1-4-Design-Guides-and-AssessmentCriteria2.aspx [Accessed $1^{\text {st }}$ December 2013].

Hartwick, E.(2006). The Impact of Environmental and Aesthetic Factors on Riverine Property Values. http://www.imagin.org/awards/sppc/2006/2006_grad_ed_hartwick.pdf (Accessed 12 April 2012).

Heikkila, E. (2000). The Economics of Planning. Center for Urban Policy Research, Rutgers University: CUPR Press

Horton Lee Brogden (HLB). (2006) Mission Creek Park North. [Online] Available from: http://www.hlblighting.com/HLB25/index.php/portfolio/mixed-use/122-missioncreekpark-north\#!MCPark_1 [Accessed $20^{\text {th }}$ November 2013]

Hubacek, K. \& Bergh, J. (2006). Changing concepts of 'land' in economic theory: From single to multi-disciplinary approaches. Ecological Economics, Vol. 56. p. 5-27. 
Kok, N. et al (2011). Economic Geography, Jobs, and Regulations: The Value of Land and Housing. [Online] Available from:

http://urbanpolicy.berkeley.edu/pdf/KMQ_Geography_JMQ_021811.pdf [Accessed $15^{\text {th }}$ April 2012].

Kondolf G.M., et. al. (2011). Connecting Cairo to the Nile: Renewing life and heritage on the river. Berkeley: Department of Landscape Architecture \& Environmental Planning, University of California.

Kruse, G. (2009).Take Me to the River: Designing the Intimate Waterfront. Master's Thesis Faculty of Virginia Polytechnic Institute and State University.

Little Rock (2008). Riverfront Park at Little Rock City. [Online] Available from: http://www.littlerock.com/!UserFiles/businesslistings/attractions/Peabody\%20Park.jpg [Accessed 15 December 2013]

Luckett, M.(2007). Design Strategies for Waterfront Revitalization in Clayton, New York. Thesis (Masters). Syracuse: State University of New York College of Environmental Science and Forestry.

Olayiwola, L., et al.(2005). Correlates of Land Value Determinants in Lagos Metropolis, Nigeria. J. Hum. Ecol., 17(3). p. 183-189

Ottawa. (2001) Design and Planning Guidelines: Street Design. [Online] Available from: http://ottawa.ca/sites/ottawa.ca/files/migrated/images/con027358_123464493.jpg [Accessed 22 ${ }^{\text {nd }}$ November 2013].

PA Consulting Group. (2009) Cleveland Waterfront Market, Demand and Development Options: Evaluating the Strategic Options for Waterfront Development on the Site of the Arlington: Cleveland- Cuyahoga County Port Authority.

Pedestrians. (2012) Sidewalk Placement. [Online] Available from:

http://www.pedestrians.org/images/whysetbacks/furnzone.jpg [Accessed $10^{\text {th }}$ October 2013]

Piwoni, J. (2006) The Historic Third Ward Neighborhood Design Guidelines, City of Milwaukee, U.S State of Wisconsin [Online] Available from:

http://city.milwaukee.gov/ImageLibrary/Groups/cityDCD/planning/plans/ThirdWard/ pdfs/ThirdWardDesign.pdf [Accessed $30^{\text {th }}$ August 2013].

Player base. (1999) A Sidewalk Café in Paris. [Online] Available from:

http://www.playerbase.com/elysium/travel/europe99/europajpgs/france/paris\%20si dewalk\%20cafe.JPG [Accessed $25^{\text {th }}$ December 2013]

Port of Los Angeles (2011). La Waterfront Design Guidelines. [Online] Available from: http://www.lawaterfront.org/images/LAWaterfront_Design_Guidelines2011.pdf Accessed (30 August 2013)

Project for Public Spaces (PPS).(2009). Benches. Public Space Amenities: Guide to Benches' Design and Management in Downtowns, Neighborhood Commercial Districts, and Parks URL: http://www.pps.org/reference/benches/. Accessed (22 September 2013)

Project for Public Spaces (PPS). (2010) How to Transform A Waterfront. [Online] Available from: http://www.pps.org/reference/turnwaterfrontaround/ [Accessed $4^{\text {th }}$ January 2013].

Richmond City Council (2012). Richmond Riverfront Plan. [Online] Available from: http://www.richmondgov.com/planninganddevelopmentreview/documents/Riverfron t_Plan_Draft_20120611.pdf [Accessed 15 ${ }^{\text {th }}$ October 2013]. 
Rodriguez, A. et al. (2001). Uneven Redevelopment: New Urban Policies and Socio-Spatial Fragmentation in Metropolitan Bilbao, European Urban and Regional Studies 8(2). p. 161-178

San Francisco Municipal Transportation Agency (SFMTA). (2013) Castro Street Design Parking Summary. [Online] Available from: http://www.google.com.eg/imgres?imgurl=xrawimage [Accessed $15^{\text {th }}$ December 2013]

Sekaran, U. \& Bougie, R. (2009) Research Methods for Business: A skill Building Approach, John Willey \& Sons Ltd, $5^{\text {th }}$ Edition.

Sign Source. (2011) Awning with painted graphics. [Online] Available from: http://www.signsource.com/gusto.html [Accessed 28 $8^{\text {th }}$ October 2013]

Skyscrapercity. (2005) The tram of Bilbao. [Online] Available from: http://www.skyscrapercity.com/showthread.php?t=210184\&page $=3 \quad$ [Accessed $20^{\text {th }}$ November 2013]

Skyscrapercity. (2011) Malacca Water Taxi. [Online] Available from: http://m6.i.pbase.com/g1/92/667992/2/127775836.CeDI6bKc.jpg [Accessed 20 ${ }^{\text {th }}$ November 2013]

Thakur, P. (2009). Assessing Land Use and Urban Form Impacts of Changes in Relative Accessibility

The Shop at Willow Bend. (2012) United Colors of Benetton. [Online] Available from: http://www.shopwillowbend.com/directory/united_colors_of_benetton [Accessed 20 November 2013]

Topcu, M. \& Kubat, A (2009). The Analysis of Urban Features that Affect Land Values in Residential Areas. Proceedings of the 7th International Space Syntax Symposium. Stockholm: KTH.

Total Branding Solutions. (2012) Projection Signs. [Online] Available from: http://www.totalbranding-solutions.co.uk/projection-signs [Accessed $28^{\text {th }}$ October 2013)

TransAlt. (2007). Rethinking Bollards: How Bollards can save lives, prevent injuries, and relief traffic congestion in New York City, [Online] Available from: http://transalt.org/files/news/reports/rethinking_bollards.pdf $\quad$ [Accessed $22^{\text {nd }}$ September 2013].

Tripadvisor. (2006) Millennium Bridge. [Online] Available from: http://mediacdn.tripadvisor.com/media/photo-s/00/18/76/67/millenniumbridge.jpg [Accessed $22^{\text {nd }}$ November 2013]

Urban Code Handbook. (2004) The Renaissance Plan for the Heart of Wake Forest, North Carolina.

Urban Research Consulting Center (URC). (2006). General Plan for the Banks of the Nile River in Greater Cairo, Third Report. Faculty of Urban and Regional Planning, Cairo University (Arabic Reference)

Waddell, P. \& Moore, T. (2008). Forecasting Demand for Urban Land in: Marzluff et al. (eds.) Urban Ecology. New York: Springer Science.

Westchester County Planning Dept. (2005). Guidelines Manual: Westchester River Walk; A Green way Trail, New York: Westchester Gov.

Wilmington Area Metropolitan Planning Organization (2008) Chapter Five: Marketing, Way finding, \& Interpretive Program. In: Cape Fear Historic Byway: Draft Corridor 
Management Plan. [Online] Available from: http://www.wmpo.org/PDF/200803_CFHBP_Chap5.pdf [Accessed 15th September 2013]. 